\title{
SENI BENJANG GULAT SEBAGAI SIMBOL IDENTITAS BUDAYA MASYARAKAT UJUNG BERUNG
}

\author{
BENJANG GULAT AS A SYMBOL OF THE IDENTITY OF UJUNG BERUNG COMMUNITY
}

\author{
Aprilla Putri Wahyuni, Neneng Yanti Khozanatu Lahpan, Yuyun Yuningsih \\ aprillaxputri@gmail.com \\ Prodi Antropologi Budaya, Fakultas Budaya dan Media \\ Institut Seni Budaya Indonesia Bandung \\ Artikel diterima:11 Januari 2021 || Artikel direvisi: 14 Januari $2021 \quad$ Artikel disetujui:21 Januari 2021
}

\begin{abstract}
ABSTRAK
Artikel ini berisi hasil penelitian mengenai perkembangan Benjang dan struktur keseniannya, pemaknaan masyarakat Ujung Berung terhadap Benjang Gulat, serta analsis terhadap simbol identitas budaya masyarakat Ujung Berung yang terdapat dalam Benjang Gulat. Penelitian ini dilakukan dengan metode deskriptif kualitatif melalui pengolahan data menggunakan teknik triangulasi. Analisis yang dilakukan menekankan identitas budaya sebagai konsep utama, serta teori interpretivisme simbolik sebagai pisau bedah dalam penelitian ini. Hasil penelitian ditinjau menggunakan sudut pandang etik dan emik, menemukan bahwa masyarakat Ujung Berung memaknai Benjang Gulat sebagai sesuatu yang penting dalam kehidupan mereka dan sudah menjadi ciri khas yang melekat dalam kebudayaan masyarakatnya, Benjang Gulat identik dengan masyarakat Ujung Berung, begitupun masyarakat Ujung Berung yang identik dengan keberadaan Benjang Gulat. Oleh karena itu, Benjang Gulat dimaknai sebagai simbol identitas budaya masyarakat Ujung Berung.
\end{abstract}

Kata Kunci: Benjang Gulat, Ujung Berung, Identitas Budaya

\section{ABSTRACT}

This article is about the development of Benjang and a structure of Benjang, the interpretation of Ujung Berung community to Benjang Gulat, and the analysis of the cultural identity symbols of Ujung Berung attached to Benjang Gulat. This study is conducted by using qualitative descriptive method with tabulation of data by using tringulasi technique. The analysis focused on cultural identity as the main concept, with the symbolic interpretivism as a theoritical framework for this study. The results are analyzed in etic and emic perspective. The results are analyzed in etic and emic perspective. The results are, Benjang Gulat is the important symbol for Ujung Berung community, that has been identified in their cultural activities, so it can be concluded that Benjang Gulat means a cultural identity symbols of Ujung Berungcommunity.

Keywords: Benjang Gulat, Ujung Berung, Cultural Identity

\section{PENDAHULUAN}

Kesenian Benjang dalam budaya masyarakat Ujung Berung memiliki posisi yang khusus dibandingkan kesenian yang lain. Benjang Gulat merupakan bentuk awal dari kesenian Benjang, seiring berjalannya waktu kesenian Benjang ini kemudian berkembang menjadi tiga jenis, yaitu Benjang helaran, Benjang Gulat/gelut, dan topeng Benjang. Ketiga jenis pertunjukan tersebut biasanya berada dalam satu rangkaian pertunjukan (Widjaya 2006). 
Benjang gulat merupakan salah satu ciri yang melekat pada masyarakat Ujung Berung, Kota Bandung. Benjang tidak dapat dilepaskan dari Ujung Berung, begitu pun dengan masyarakat Ujung Berung yang terikat erat dengan kesenian Benjang. Pada tahun 2019, Benjang ditetapkan sebagai warisan budaya tak benda Indonesia oleh Kementerian Pendidikan dan Kebudayaan Republik Indonesia.

Benjang selalu ditampilkan hampir pada setiap acara, misalnya khitanan dan acara penting lainnya di wilayah Ujung Berung. Menjadi suatu kebanggaan bagi masyarakat Ujung Berung jika menampilkan kesenian Benjang pada setiap acara-acara penting. Oleh karena itu, penulis tertarik untuk meneliti bagaimana pemaknaan masyarakat Ujung Berung terhadap Benjang Gulat sebagai simbol identitas budayanya.

Sebagai kesenian yang populer di Ujung Berung, Benjang telah menarik banyak perhatian para peneliti. Akan tetapi, kebanyakan yang menjadi topik penelitian merupakan Benjang helaran atau topeng Benjang, adapun penelitian mengenai Benjang Gulat yang penulis temukan belum ada satu pun di antaranya yang membahas mengenai seni Benjang Gulat sebagai simbol identitas budaya masyarakat Ujung Berung. Padahal, Benjang Gulat berperan penting dalam identitas masyarakat Ujung Berung.

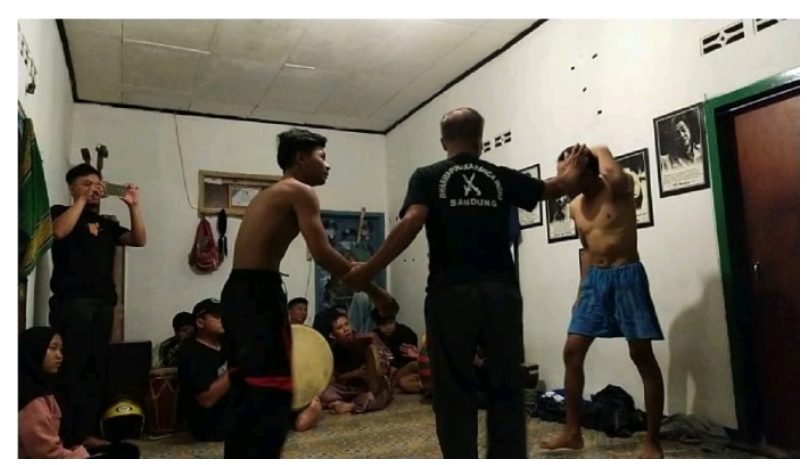

Gambar 1. Foto sesi latihan Benjang Gulat di Paguron Dharma Pusaka Panca Indra.

(Foto: Aprilla, 2020).

Penelitian ini dilakukan untuk mendeskripsikan perkembangan Benjang dan struktur keseniannya, menjelaskan pemaknaan masyarakat Ujung Berung terhadap seni bela diri Benjang Gulat, dan menjelaskan simbol identitas budaya masyarakat Ujung Berung yang terdapat dalam Benjang Gulat. Penelitian ini dilakukan sebagai upaya untuk memperoleh konsep baru dan memberikan kontribusi terhadap pengembangan ilmu khususnya ilmu antropologi. Selain itu, penelitian ini diharapkan dapat memberi kontribusi ilmiah pada kajian tentang Benjang khususnya terkait pembentukan identitas budaya suatu masyarakat dan diharapkan dapat menjadi referensi bagi penelitian-penelitian berikutnya.

Penulis menggunakan sejumlah konsep yang relevan dengan penelitian terkait Benjang Gulat ini, yakni: 1) kesenian tradisional 2) Benjang, 3) identitas budaya 4) simbol dan pemaknaan. Takari dkk (2008), menggambarkan kesenian tradisional sebagai suatu jenis kesenian yang identik atau berasal dari suatu daerah. Benjang Gulat dalam Irmadani (2015) dijelaskan memiliki nilai sebagai salah satu identitas bangsa dan merupakan kesenian asli dari Ujung Berung.

Penelitian ini menekankan identitas budaya sebagai konsep utama, yang terdapat pada seni bela diri Benjang Gulat. Terkait dengan hal itu, penulis merumuskan sejumlah konsep dari para ahli yaitu konsep identitas budaya menurut Rice (1990) dan teori interpretativisme simbolik menurut Geertz untuk mengungkap identitas budaya melalui pemaknaan simbol dalam Benjang Gulat. Dalam hal ini, konsep mengenai identitas budaya merupakan produk budaya yang menurut perspektif Rice sebagai sesuatu yang pasti dan esensial yang tertata berdasar kaidah adanya perbedaan yang bersifat state of being. Perspektif Rice tentu berbeda dengan perspektif lain yang beranggapan identitas budaya bukan sesuatu yang pasti dan esensial karena tiada lain senantiasa becoming sebagaimana pendapat Stuart Hall (lihat penjelasan Setyobudi 2017: 56). 
Sementara itu, teori interpretatif simbol menurut Geertz (1992), bahwa kebudayaan adalah sesuatu yang bersifat semiotik, yang berhubungan dengan simbol, tampak di depan umum dan dikenal oleh masyarakat bersangkutan. Dapat ditelaah bahwa budaya menurut Geertz adalah suatu makna dan simbol yang mana individu bisa mengekspresikan dunianya. Sesuatu yang berhubungan dengan simbol, dan hal tersebut dikenal di kalangan masyarakat. Jadi simbol adalah sesuatu yang perlu ditafsirkan maknanya. Teori interpretivisme simbolik Geertz digunakan sebagai pisau bedah dalam penelitian ini untuk mengkaji pemaknaan masyarakat Ujung Berung terhadap Benjang Gulat sebagai simbol identitas budayanya.

\section{METODA}

Penelitian ini menggunakan metode penelitian kualitatif. Menurut Setyobudi mengutip Boije, bahwa penelitian kualitatif mengandung tiga unsur penting: looking for meaning, using flexible research methods enabling contact, dan providing qualitative findings. Tiga unsur penting ini bertujuan to describe dan to understand social phenomena (2020: 19). Dengan demikian, metode penelitian kualitatif selaras dengan tujuan penelitian ini yang berupaya menggali simbol-simbol yang terdapat pada Benjang Gulat yang menjadi pembentuk identitas budaya masyarakat Ujung Berung. Oleh karena itu, penulis memperhatikan dua sudut-pandang antara etik dan emik. Emik dalam penelitian ini, yaitu berdasarkan sudut pandang pelaku seni Benjang, budayawan, dan masyarakat Ujung Berung. Sedangkan, etik dalam penelitian ini, yaitu berdasarkan sudut pandang penulis dalam membaca fenomena yang terjadi di dalam kesenian Benjang dan kehidupan masyarakat Ujung Berung. Selain itu, sudut pandang etik dalam menafsirkan simbol yang terdapat pada kesenian Benjang terkait hubungannya dengan proses pembentukan identitas masyarakat Ujung Berung, tidak semata berdasarkan pandangan penulis saja, melainkan lebih menekankan pada ketelitian penulis dalam membaca simbol tersebut berdasarkan fakta fenomena yang terjadi.

Dalam penelitian ini, penulis menggunakan beberapa teknik pengumpulan data yaitu observasi, wawancara, dan dokumentasi. Observasi dilakukan dengan dua cara yakni, secara langsung menonton di lapangan dan tidak langsung yang melalui media online (youtube). Wawancara dilakukan dengan beberapa narasumber, yaitu seniman atau pelaku Benjang Gulat, budayawan yang memahami Benjang Gulat secara detail dan masyarakat Ujung Berung. Tahapan wawancara yang dilakukan terdiri dari dua tahap. Tahap pertama, peneliti mendengarkan apa yang diceritakan oleh informan terkait dengan kesenian Benjang. Tahap kedua, menggunakan cara obrolan yang lebih dalam terhadap permasalahan tujuan penelitian yaitu terkait Benjang Gulat dan simbol identitas budaya masyarakat Ujung Berung. Dokumentasi dilakukan dengan fokus utama yakni penyelidikan terhadap aspek-aspek dari seni bela diri Benjang Gulat dan keseharian masyarakat Ujung Berung. Metode ini dilakukan dengan mengumpulkan data yang diperoleh dari dokumen-dokumen yang ada dan catatan-catatan yang tersimpan. Dokumentasi pada penelitian ini juga dilakukan sebagai pelengkap data dengan mengambil beberapa foto, video, dan audio ketika melakukan observasi dan wawancara. Data yang diperoleh dari berbagai sumber dengan melalui berbagai tahapan metode pengumpulan data tersebut kemudian diolah menggunakan metode analisis data. Pada tahap ini, penulis menggunakan teknik triangulasi data.

\section{HASIL DAN PEMBAHASAN}

Benjang Gulat merupakan seni bela diri tradisional yang populer di wilayah Ujung Berung. Kesenian ini termasuk ke dalam jenis kesenian rakyat yang memadukan antara bela diri dengan tarian. Pertunjukan Benjang Gulat diiringi dengan beberapa macam alat musik, di antaranya terebang, bedug, terompet, kecrek, dan kendang. 


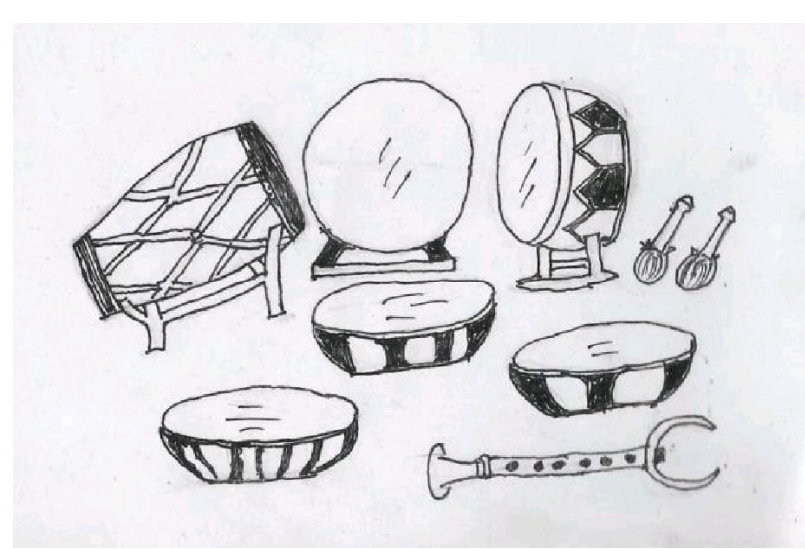

Gambar 2. Ilustrasi waditra Benjang Gulat.

(Gambar hasil observasi: Aprilla, 2020)

Adapun struktur (urutan penyajian) pertunjukan Benjang Gulat diawali dengan 1) musik pembuka, 2) kemudian sambutan yang dilakukan oleh pelaksana. Setelah itu, 3) pemanasan dilakukan oleh para atlet Benjang yang akan bertanding, 4) dilanjutkan dengan "saling naksir", yaitu upaya untuk saling mengukur kekuatan fisik lawan, lalu pemain masuk kearena pertandingan sambil membuka baju dan dikenal dengan istilah "mesek". Kemudian, 5) pertandingan diakhiri dengan jabat tangan dan pelukan antar pemain Benjang sebagai tanda persahabatan. Terakhir 6) pertunjukan Benjang ditutup dengan kata penutup oleh protokol sebagai tanda pertunjukan telah selesai.
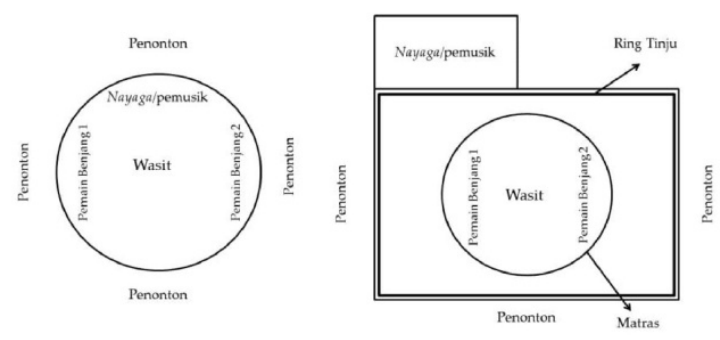

Gambar 3. Denah arena pertunjukan Benjang Gulat. (Gambar hasil observasi: Aprilla, 2020)

Benjang Gulat sebagai salah satu wujud kebudayaan tentu memiliki pola makna, sebagai bentuk komunikasi atau sebuah pesan yang dituangkan dalam bentuk simbol-simbol di dalamnya. Sebagaimana kebudayaan menurut Geertz (1992), adalah sesuatu yang bersifat semiotik, yang berhubungan dengan simbol, sebuah pola dari makna-makna yang tampak di depan umum dan dikenal oleh masyarakat bersangkutan. Makna-makna itu tertuang dalam bentuk simbol-simbol yang diwariskan dan diungkapkan sebagai suatu bentuk komunikasi. Simbol juga merupakan objek, kejadian, bunyi bicara, atau bentuk-bentuk tertulis yang diberi makna oleh manusia (Geertz dalam Pranata dan Ikhsan, 2018). Dalam kesenian Benjang Gulat, simbol-simbol tampak pada gerakan-gerakannya.

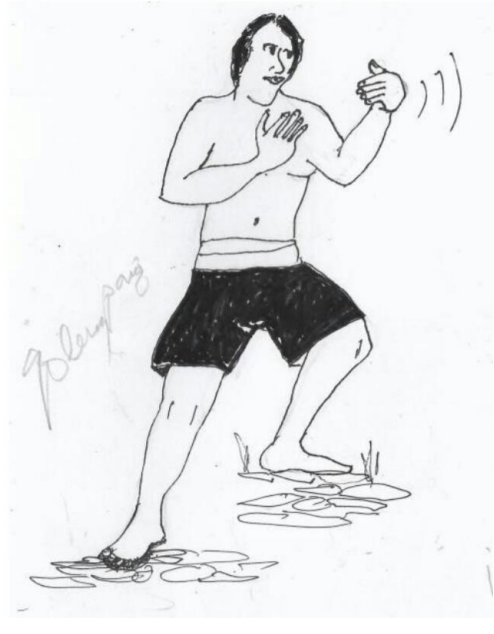

Gambar 4. Ilustrasi gerakan Golempang. (Gambar hasil observasi: Aprilla, 2020)

Golempang sebagai gerakan yang menyimbolkan penghormatan terhadap penonton yang hadir. Gerakan pemanasan yang hampir mirip dengan gerakan pencak silat. Gerakan ini juga bermakna bahwa manusia harus hormat terhadap sesama, tidak memandang peran dan kedudukan (Wawancara Bapak Endang Sapaat, 63 tahun, sebagai wasit Benjang Gulat). Karena Ujung Berung berada di wilayah Jawa Barat, maka jika dilihat lebih jauh, pemaknaan ini juga berkaitan dengan karakteristik masyarakat Sunda yang menjunjung tinggi tata-titi, yaitu etika (sopan-santun) terhadap sesama manusia (Mustapa, 1985).

Saling Naksir juga merupakan salah satu gerakan dalam pertunjukan Benjang Gulat yang dimaknai oleh masyarakat Ujung Berung sebagai gerakan yang menyimbolkan tantangan terhadap lawan. Gerakan ini juga bermakna 
bahwa walaupun dekat satu sama lain, manusia harus selalu waspada dan dapat mengukur kemampuan masing-masing (Wawancara Deyanalisa, 48 tahun, sebagai masyarakat Ujung Berung).

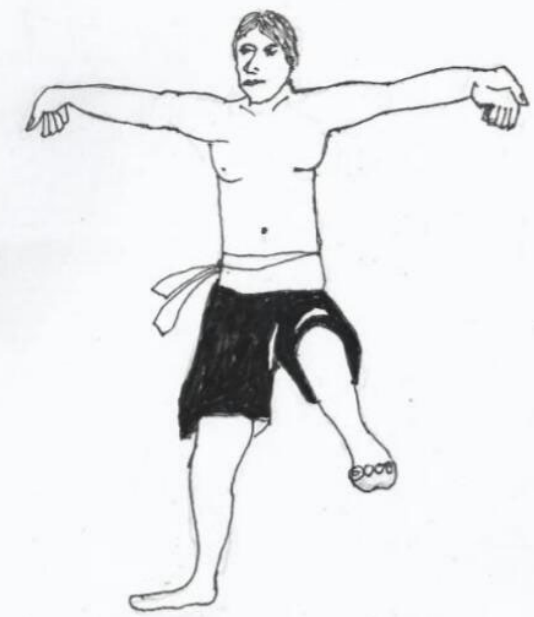

Gambar 5. Ilustrasi gerakan Heulang Ngapak.

(Gambar hasil observasi: Aprilla, 2020)

Selain itu, ada pula gerakan Heulang Ngapak dalam pertunjukan Benjang Gulat dimaknai oleh masyarakat Ujung Berung sebagai gerakan yang menyimbolkan keangkuhan seseorang. Heulang Ngapak merupakan gerakan yang menyerupai burung elang, pebenjang mengangkat kedua tangan seolah sedang mengepakan sayap. Gerakan ini juga bermakna bahwa kita tidak boleh terlihat lemah dihadapan lawan (Wawancara Asep Gowil, 38 tahun, sebagai pelaku seni Benjang Gulat).

Penjelasan ini berkaitan dengan kedudukan Benjang Gulat di masyarakat Ujung berung sebagai aspek yang berpengaruh, terutama bagi harga diri masyarakat di masing- masing daerahnya. Maka dari itu para pebenjang yang mewakili daerahnya, harus tampak kuat dan hebat demi menjaga nama baik daerah asal mereka.

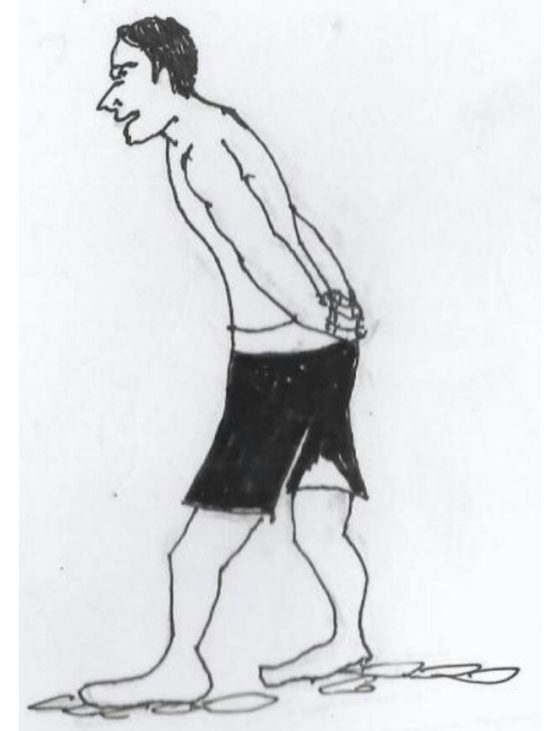

Gambar 6. Ilustrasi gerakan Puyuh Ngungkug. (Gambar hasil observasi: Aprilla, 2020)

Puyuh Ngungkug juga sebagai salah satu gerakan dalam pertunjukan Benjang Gulat, dimaknai oleh masyarakat Ujung Berung sebagai gerakan yang menyimbolkan pengamatan terhadap lawan. Puyuh Ngungkug adalah gerak tarian dengan posisi tubuh agak membungkuk dan posisi tangan ke belakang. Posisi kepala menunduk disertai gerakan kekiri dan ke kanan dengan kaki yang melangkah ke depan saling bergantian. Gerakan ini merupakan gambaran dari seekor buruh puyuh yang sedang berjalan. Gerakan ini bermakna bahwa kita harus teliti dalam mengamati keadaan (Wawancara bapak Dedi Supriyadi, 35 tahun, sebagai pelaku seni Benjang Gulat).

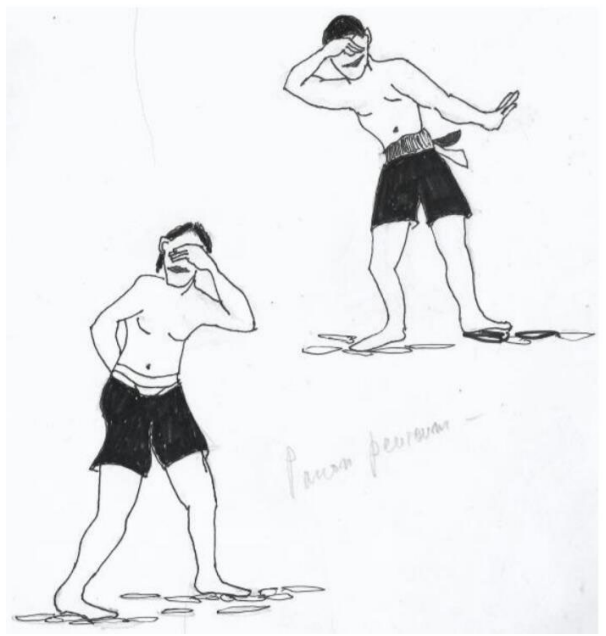

Gambar 7. Ilustrasi gerakan Panon Peureum. (Gambar hasil observasi: Aprilla, 2020) 
Gerakan yang lain yaitu Panon Peureum, dimaknai oleh masyarakat Ujung berung sebagai gerakan yang menyimbolkan penghayatan. Panon diambil dari bahasa Sunda yang artinya mata, begitupun peureum yang artinya terpejam. Gerakan ini dilakukan dengan posisi tubuh agak membungkuk dan sebelah tangan menutupi area wajah dengan mata yang terpejam. Tangan yang lainnya lurus ke belakang dan digerakkan mengikuti irama tabuhan dari nayaga, sedangkan kedua kaki bergerak ke depan salingbergantian.

Gerakan Ibingan juga berperan penting dalam pertunjukan Benjang Gulat, dimaknai oleh masyarakat Ujung berung sebagai gerakan yang menyimbolkan harmonisasi. Ibing diambil dari bahasa Sunda yang artinya tari. Gerakan ini lebih menekankan kepada gerakan ekspresi individu, maka pebenjang bisa menari dengan bebas sesuai dengan keinginannya dengan tetap memerhatikan harmonisasi dengan musik pengiring. Pemaknaan tersebut tampak pada ekspresi dan gerak tubuh pebenjang yang selaras dengan musik pengiringnya.

Geertz (1992) dalam penelitiannya mengenai Sabung Ayam di Bali pada tahun 1958 juga menafsirkan kebudayaan melalui pendekatan etik dan emik, sama halnya dengan yang penulis lakukan dalam penelitian ini. Etik dan emik adalah landasan penelitian yang digunakan untuk memahami tingkah laku manusia. Di mana tingkah laku itu penuh dengan makna, karena di dalamnya terdapat berbagai simbol (Endraswara, 2003:34).

\section{A. Makna Simbol Benjang Gulat secaraEmik}

Berdasarkan hasil penelitian yang dilakukan penulis, makna Benjang Gulat secara Emik meliputi tiga hal, yaitu: 1) unjuk kekuatan fisik, 2) ekspresi, dan 3) bentuk komunikasi/ penyampaian pesan.

\section{Unjuk Kekuatan Fisik}

Pertunjukan Benjang Gulat tidak dapat dilepaskan dari adanya adu kekuatan fisik dalam sesi pertandingannya. Maka, pertunjukan Benjang Gulat dimaknai sebagai ajang untuk unjuk kekuatan fisik (para pebenjang). Terlebih dengan adanya predikat "menang" dan "kalah", di mana pebenjang yang menang akan dianggap lebih kuat daripada pebenjang yang kalah. Hal itu akan menjadi suatu kebanggaan bagi pebenjang yang menang dan masyarakat daerah pebenjang itu berasal.

Oleh karena itu dalam pertunjukan Benjang Gulat, eksistensi pebenjang dan aktualisasi diri menjadi salah satu poin penting. Keadaan ini sesuai dengan definisi Geertz mengenai kebudayaan yang merupakan suatu sistem keteraturan dari makna dan simbol-simbol, yang dengan simbol itu para individu mendefinisikan dunia mereka, mengekspresikan perasaan-perasaan mereka, dan membuat penilaiannya.

\section{Ekspresi}

Manusia melakukan gerakan (menari) untuk menyalurkan perasaan, sama halnya dengan yang dilakukan oleh hewan. Gerakan tariannya bukan hanya diperkuat dengan loncatan, lompatan, dan gerakan kaki, namun juga didukung dengan emosi yang intens (Takari dkk, 2008). Oleh karena kesamaan itu, manusia cenderung menggunakan representasi hewan dalam berkarya seni.

Seni Benjang Gulat menyiratkan representasi hewan di beberapa istilah gerakannya, yaitu Heulang Ngapak, Puyuh Ngungkug, dan Mumundingan. Istilah untuk gerakan-gerakan tersebut diambil dari berbagai jenis hewan. Hal ini berkaitan dengan bentuk atau struktur tubuh hewan serta ekspresi yang ada pada hewan yang hampir menyerupai bentuk dan ekspresi yang ada pada manusia. Gerakan-gerakan itu memiliki gaya dan ekspresi yang menyerupai hewan yang ada dalam istilah yang digunakannya. Misalnya Heulang Ngapak, gerakannya menyerupai burung elang yang sedang mengepakkan sayapnya, Puyuh Ngungkug yang gerakannya menyerupai burung puyuh yang sedang berjalan, dan Mumundingan yang gerakannya 
Aprilla, Neneng, Yuyun - Seni Benjang Gulat sebagai.....

saling mendorong kepala lawan layaknya dua ekor kerbau yang sedang beradu.

Setiap gerakan itu memiliki makna yang berkaitan dengan karakteristik gerakan dari hewan yang digunakan dalam setiap istilahnya. Jika merujuk pada pandangan Geertz dalam teori interpretivisme simbolik yang mengatakan simbol adalah objek, maka sama halnya dengan gerakan-gerakan pada Benjang Gulat sebagai media atau objek untuk merepresentasikan sesuatu, dalam hal ini ialahhewan.

\section{Bentuk Komunikasi}

Pemaknaan Benjang Gulat sebagai bentuk komunikasi terdapat pada gerakan dan lagu yang terdapat pada pertunjukannya. Misalnya, pada gerakan Golempang yang gerakannya berputar menghadap empat penjuru mata angin, sebagai penghormatan pada para penonton yang hadir. Selain itu, ada pun gerakan Saling Naksir yang memberi komunikasi pada pebenjang lawan bahwa ia sedang diamati atau memberi pesan pada penonton bahwa para pebenjang sedang saling mengamati satu sama lain.

Keadaan ini berkaitan dengan teori interpretivisme simbolik Geertz, mengenai makna-makna kebudayaan yang tertuang dalam bentuk simbol-simbol yang diungkapkan sebagai suatu bentuk komunikasi. Kejadian di mana pebenjang memberi hormat pada penonton atau saling mengamati satu sama lain melalui gerakan, merupakan sebuah simbol yang makna atau pesannya sampai kepada masyarakat walaupun secara tidak langsung. Isyarat atau gerakan ini menjadi simbol penting dalam kehidupan masyarakat, karena melalui gerakan dapat tersampaikan sebuah makna atau pesan. Berkaitan dengan simbol, yang mana dengan makna tersebut setiap individu mendefinisikan dunia mereka, mengekspresikan perasaanperasaan mereka, dan membuat penilaian mereka (Geertz,1992).

\section{B. Makna Simbol Benjang Gulat secara Etik}

Selain makna secara emik, penulis juga menganalisis makna simbol yang ada pada Benjang Gulat secara etik. Makna Benjang Gulat secara etik meliputi tiga hal, yaitu: 1) Makna Pendidikan, 2) Makna Solidaritas, dan 3) Makna Estetika.

\section{Makna Pendidikan}

Rata-rata pebenjang telah mengenal dan berlatih Benjang Gulat sejak sekolah dasar dan sekolah menengah pertama. Hal itu dilakukan salah satunya agar waktu bermain dapat diisi dengan hal yang lebih bermanfaat, selain itu sebagai pembelajaran terkait teknik bela diri dan olahraga.

Hal tersebut merujuk pada pandangan Geertz dalam teori interpretivisme simbolik mengenai kebudayaan yang didasarkan kepada penafsiran, melalui penafsiran itu mengontrol sikap dan tindakan untuk diinterpretasikan dalam kehidupan mereka. Pada Benjang Gulat, pelatihan dilakukan sejak dini agar pebenjang dapat mengontrol teknik bela diri mereka ketika sudah dewasa. Selain itu, agar para pebenjang tidak menyalahgunakan kemampuan yang mereka miliki.

\section{Makna Solidaritas}

Solidaritas berupa suatu keadaan hubungan antara individu atau kelompok yang berdasar pada keadaan moral yang diperkuat oleh keadaan emosional yang dialami bersama (Johnson, 1994:81). Pada fenomena dalam seni Benjang Gulat, solidaritas dapat terlihat dari dukungan yang dilakukan oleh penonton kepada pebenjang yang berasal dari daerah yang sama dengannya. Jika pebenjang menang, maka warga daerah asalnya akan ikut merasa bangga.

Selain itu, melihat fenomena pada tahun 1970-an ketika dikeluarkan larangan untuk menggelar pertunjukan benjang gulat dengan alasan sering terjadinya tawuran antar warga yang diakibatkan oleh adanya pertunjukan Ben- 
jang Gulat, membuktikan tingginya rasa solidaritas antar masyarakat yang tercipta melalui Benjang Gulat.

Geertz (1992) dalam teori interpretivisme simbolik mengungkapkan bentuk primer dari simbolisasi adalah melalui bahasa. Tetapi, manusia juga berkomunikasi dengan tanda dan simbol salah satunya dalam kekerabatan dan nasionalitas. Pada fenomena dalam Benjang Gulat, misalnya masyarakat daerah "A" akan mendukung pebenjang yang berasal dari daerah "A" juga, begitu pun masyarakat daerah "B", "C", dan seterusnya. Jika pebenjang yang didukung kalah, masyarakat akan merasa kecewa, atau jika pebenjang yang didukung dirasa telah dicurangi maka akan masyarakat biasanya akan turun tangan untuk membela pebenjang yang didukungnya. Oleh karena itu, Benjang Gulat merupakan salah satu simbol solidaritas masyarakat Ujung Berung.

\section{Makna Estetika}

Benjang Gulat yang memiliki fungsi hiburan tentu memiliki makna estetika. Hal ini tampak dalam harmonisasi antara musik pengiring dalam pertunjukan Benjang Gulat dengan gerakan yang dilakukan oleh pebenjang. Jika merujuk pada pandangan Geertz dalam teoriinterpretivisme simbolik yang mengatakan simbol adalah objek, maka pertunjukan Benjang Gulat dalam hal ini merupakan sebuah objek yang memliki makna estetis.

\section{Benjang Gulat sebagai Pemberi Identitas}

Benjang Gulat merupakan simbol identitas masyarakat Ujung Berung yang bermakna bahwa Benjang Gulat merupakan milik masyarakat Ujung Berung. Seperti yang telah dipaparkan pada sub-bab sebelumnya mengenai Benjang Gulat sebagai simbol, bahwa masyarakat Ujung Berung tidak dapat lepas dari keberadaan Benjang Gulat, begitupun keberadaan Benjang Gulat yang tidak dapat terlepas dari peran penting masyarakat Ujung Berung.

Rice (1990:202) memandang bahwa identitas budaya adalah jumlah keseluruhan dari perasaan seseorang atau anggota kelompok terhadap simbol-simbol, nilai-nilai, dan sejarah umum yang membuat mereka dikenal sebagai suatu kelompok yang berbeda. Pandangan ini berkaitan dengan bahasan pada sub-bab sebelumnya mengenai simbol dan makna yang terdapat dalam seni Benjang Gulat. Hasil penelitian ini mendapati Benjang Gulat sebagai sebuah simbol yang memiliki nilai-nilai (makna) serta sejarah (kedudukan) penting bagi masyarakat Ujung berung.

Hasil penelitian yang dilakukan oleh penulis juga mendapati semua narasumber memiliki pendapat yang sama bahwa Benjang Gulat merupakan sesuatu khas yang dimiliki oleh masyarakat wilayah Ujung Berung. Hal ini merujuk pada pandangan Rice mengenai identitas budaya yang menyatakan bahwa identitas budaya berupa jumlah keseluruhan dari perasaan seseorang atau anggota kelompok. Dalam penelitian ini, anggota kelompok tersebut ialah masyarakat Ujung Berung dalam memandang simbol-simbol, nilai-nilai, dan sejarah umum yang terdapat pada Benjang Gulat yang membuat mereka dikenal sebagi suatu kelompok yang berbeda. Hal ini berkaitan dengan kepemilikan masyarakat Ujung Berung terhadap Benjang Gulat dan istilah Benjang Gulat yang melekat pada masyarakat Ujung Berung, begitupun sebaliknya.

Penulis melihat identitas budaya merujuk pada pendapat Rice, bahwa hal itu merupakan sesuatu yang otentik dan esensial melalui dua cara pandang. Dalam cara pandang pertama, identitas budaya dilihat sebagai satu kesatuan yang dimiliki bersama atau berupa bentuk dasar seseorang serta berada dalam diri banyak orang yang memiliki kesamaan sejarah dan leluhur. Sedangkan dalam cara pandang kedua, identitas budaya dilihat sebagai suatu proses yang terjadi dan diikuti oleh seseorang atau sekelompok orang baik secara sadar maupun tidak, baik langsung maupun tidak langsung.

Pada cara pandang pertama, identitas budaya masyarakat Ujung Berung dilihat sebagai satu kesatuan yang dimiliki bersama, 
Aprilla, Neneng, Yuyun - Seni Benjang Gulat sebagai.....

dalam hal ini Benjang Gulat sebagai salah satu pemberi identitas yang berada dalam diri masyarakat Ujung Berung. Sedangkan pada cara pandang kedua, adanya pertunjukan Benjang Gulat mengundang masyarakat Ujung Berung untuk datang dan menonton. Sering diadakannya pertunjukan Benjang Gulat ini menumbuhkan rasa solidaritas antar masyarakat, bentuk solidaritas itu tampak pada antusiasme masyarakat yang datang ke arena pertunjukan Benjang Gulat untuk mendukung pebenjang dari daerahnya masing-masing. Solidaritas tersebut semakin lama semakin menumbuhkan rasa kepemilikan atas kesenian Benjang Gulat dan menjadi simbol kebanggaan (gengsi) yang terus melekat dalam diri masyarakat Ujung Berung, yang kemudian dimaknai sebagai identitas budayanya.

\section{SIMPULAN}

Masyarakat Ujung Berung memaknai Benjang Gulat sebagai sesuatu yang penting dalam kehidupan mereka. Benjang sudah menjadi ciri khas yang melekat dalam kebudayaan masyarakat Ujung Berung. Mereka juga merasakan kepemilikan yang kuat terhadap kesenian Benjang Gulat dan menganggapnya sebagai warisan yang menjadi kebanggaan bagi masyarakat Ujung Berung.

Secara garis besar dapat dilihat bahwa Benjang Gulat merupakan suatu simbol, karena aspek-aspek (terutama gerakan) yang terdapat di dalamnya dimaknai berdasarkan kesepakatan oleh masyarakat Ujung Berung. Berkaitan dengan itu, adanya pertunjukan Benjang Gulat, menumbuhkan solidaritas di masyarakat Ujung Berung. Solidaritas itu menumbuhkan rasa kepemilikan atas kesenian Benjang Gulat dan berubah menjadi simbol kebanggaan (gengsi) yang terus melekat dalam diri masyarakat Ujung Berung yang kemudian dimaknai sebagai identitas budayanya.

\section{DAFTAR PUSTAKA}

Endraswara, S. (2003). Metodologi Penelitian

Sastra. Yogyakarta: Pustaka Widyatama.

Erniwati. (2011). China Padang Dalam Dinamika Masyarakat Minangkabau: Dari Revolusi Sampai Reformasi. Jakarta: Universitas Indonesia.

Geertz, C. (1992). Kebudayaan dan Agama (Terjemahan). Yogyakarta:Kanisius.

Geertz, C. (1992). Tafsir Kebudayaan. Yogyakarta: Kanisius.

Irmadani, D. (2018). Perkembangan Seni Beladiri Gulat Benjang Di Ujung Berung Tahun 2000- 2015. Bandung: UIN Sunan Gunung Djati.

Johnson, D. P. (1994). Teori Sosiologi Klasik Dan Modern. Jakarta: Gramedia Pustaka.

Leonardo Pranata, Rizal Ikhsan. (2018). Ritual Tari Tauh dalam Kenduri SKO (Studi

Intepretivisme Simbolik: Masyarakat Desa Lolo Hilir. Jurnal Sejarah, Budaya, dan Pengajarannya, 49-59.

Muhammad Takari, DKK. (2008). Masyarakat Kesenian Di Indonesia. Medan: Studia Kultura.

Mustapa, H. (1985). Adat Istiadat Orang Sunda (Terjemahan Oleh Maryati Sastrawijaya). Bandung: Alumni.

Rice, F. P. (1990). The Adolescent, Development, Relationship \& Culture. Boston: Ally \& Bacon.

Setyobudi, I. (2020). Metode Penelitian Budaya: Desain Penelitian dan Tiga Model Kualitatif: Life History, Grounded Theory, dan Narrative Personal. Bandung: Sunan Ambu Press. Setyobudi, I. (2017). Politik Identitas animal pop dance: Subbudaya dan Gaya Hidup Hibrid. Jurnal Sosiologi Reflektif Volume 12 Nomor 1. Yogyakarta: Laboratorium Sosiologi Fakultas Ilmu Sosial dan Humaniora UIS Sunan Kalijaga. 
Jurnal Budaya Etnika, Vol. 5 No. 1 Juni 2021

Widjaya, A. S. (2006). Benjang Dari Seni Terebangan Ke Seni Bela Diri dan
Pertunjukan. Bandung: Panitia Festival Benjang Anak II. 